\title{
Occurrence of Neospora caninum and Toxoplasma gondii antibodies in dogs from rural properties surrounding a biological reserve, Espirito Santo, Brazil
}

Ocorrência de anticorpos anti-Neospora caninum e Toxoplasma gondii em cães de propriedades rurais do entorno de uma reserva biológica, Espírito Santo, Brasil

Igor da Cunha Lima Acosta ${ }^{1}$; Luana D’Avila Centoducatte²; Herbert Sousa Soares ${ }^{1}$; Arlei Marcili ${ }^{1,3}$;

Maria Fernanda Naegeli Gondim'; João Luiz Rossi Junior'; Solange Maria Gennari ${ }^{1 *}$

\begin{abstract}
${ }^{1}$ Departamento de Medicina Veterinária Preventiva e Saúde Animal, Faculdade de Medicina Veterinária e Zootecnia, Universidade de Sáo Paulo - USP, São Paulo, SP, Brasil

${ }^{2}$ Departamento de Ciências Biológicas, Centro de Ciências Humanas e Naturais, Universidade Federal do Espírito Santo - UFES, Vitória, ES, Brasil

${ }^{3}$ Programa de Pós-graduaçăo em Medicina Veterinária e Bem Estar Animal, Universidade de Santo Amaro - UNISA, São Paulo, SP, Brasil

${ }^{4}$ Programa de Pós-graduaçăo em Ciência Animal, Universidade Vila Velha - UVV, Vila Velha, ES, Brasil
\end{abstract}

Received June 10, 2016

Accepted October 4, 2016

\begin{abstract}
The aim of this study was to determine the presence of antibodies to Neospora caninum and Toxoplasma gondii in serum samples of 187 dogs from 30 rural properties surrounding Córrego do Veado Biological Reserve, Espírito Santo State, Brazil. The Reserve is one of the last lowland Atlantic Forest remnants of the region, surrounded by agriculture farms and cattle pastures. The presence of IgG antibodies was determined by the Indirect Fluorescent Antibody Test for T. gondii (cut-off 1:16) and $N$. caninum (cut-off 1:50). Positive samples were diluted 2-fold until the last positive dilution. Antibodies to T. gondii were found in 77 (47.05\%) dogs and antibodies to N. caninum in 22 dogs (11.76\%) and one only dog was positive for both infections. No association between T. gondii and N. caninum infection and sex was observed $(p>0.05)$. Control measures to prevent those infections in dogs that living surrounding the reserve and that had contact with wild animals are important to avoid the introduction of $N$. caninum in wild animals. This was the first study of frequency of occurrence of T. gondii and N. caninum in dogs from Espírito Santo, Brazil.
\end{abstract}

Keywords: Neospora caninum, Toxoplasma gondii, dogs, Atlantic Forest.

\section{Resumo}

O objetivo deste estudo foi determinar a presença de anticorpos contra Neospora caninum e Toxoplasma gondii em amostras de soro de 187 cáes de 30 propriedades rurais do entorno da Reserva Biológica Córrego do Veado, Espírito Santo, Brasil. A Reserva é um dos últimos remanescentes de Mata Atlântica da região, cercada por fazendas com agricultura e pastagens. A presença de anticorpos IgG foi determinada pela reação de imunofluorescência indireta para T. gondii (ponto de corte de 1:16) e para $N$. caninum (ponto de corte de 1:50). As amostras positivas foram diluídas na base dois e tituladas. Anticorpos para T. gondii foram encontrados em 77 (47,05\%) cães e para N. caninum em $22(11,76 \%)$. Um cão foi positivo para ambas as infecçôes. Não houve associaçấo entre a infecção pelo T. gondii e $N$. caninum e o sexo $(p>0,05)$. Medidas de controle, para prevenir essas infecçôes em cáes que vivem no entorno da reserva e com possibilidade de contato com animais selvagens, são importantes para evitar a introdução de $N$. caninum nos animais selvagens. Este foi o primeiro relato da frequência de anticorpos contra estes coccídios em cáes do Espírito Santo, Brasil.

Palavras-chave: Neospora caninum, Toxoplasma gondii, cães, Mata Atlântica.

\footnotetext{
*Corresponding author: Solange Maria Gennari. Departamento de Medicina Veterinária Preventiva e Saúde Animal, Faculdade de Medicina Veterinária e Zootecnia, Universidade de Sáo Paulo - USP, Av. Prof. Orlando Marques de Paiva, 87, Cidade Universitária, CEP 05508-270, São Paulo, SP, Brasil. e-mail: sgennari@usp.br
} 
Toxoplasma gondii is a coccidian parasite found worldwide. It infects virtually all warm-blooded animals, including humans but only cats (domestic and wild) are its definitive hosts (DUBEY, 2010). Neospora caninum is also a coccidian parasite with a similar host range but canids are definitive hosts (MCALLISTER et al., 1998; GONDIM et al., 2004; KING et al., 2010; DUBEY et al., 2011). It causes mortality in dogs (DUBEY \& LINDSAY, 1996) and abortion in cattle (ANDERSON et al., 1995; CORBELLINI et al., 2002).

In Brazil T. gondii is a common parasite, and the infection in dogs ranges from $2.6 \%$ to $90 \%$ (revised by DUBEY et al., 2012; FOURNIER et al., 2014; LOPES et al., 2011, 2015; RAIMUNDO et al., 2015). Also common, $N$. caninum is found to infect dogs in rates that go from $2.6 \%$ to $67.6 \%$ (revised by DUBEY, 2013).
In the State of Espírito Santo, information related to these parasites in dogs is not available. In this State, in the municipality of Pinheiros, is located the Córrego do Veado Biological Reserve, a protected area (2.357 ha) and one of the last lowland Atlantic Forest remnants of the region. Agriculture and cattle farms surround all the Reserve. Companion animals, mostly dogs, are often present and, because they are close to the forest, they can easily get in contact with wild animals. The objective of this study was to determine the frequency of occurrence of antibodies to T. gondii and N. caninum in dogs living in rural environment close to a forest matrix, in the state of Espírito Santo, where no data is available.

The present study was conducted in 30 rural properties surrounding the Córrego do Veado Biological Reserve (Figure 1), municipality of Pinheiros, State of Espírito Santo, southeastern region of Brazil ( $\left.40^{\circ} 08^{\prime} 48^{\prime \prime} \mathrm{S}, 18^{\circ} 20^{\prime} 33^{\prime \prime} \mathrm{W}\right)$.
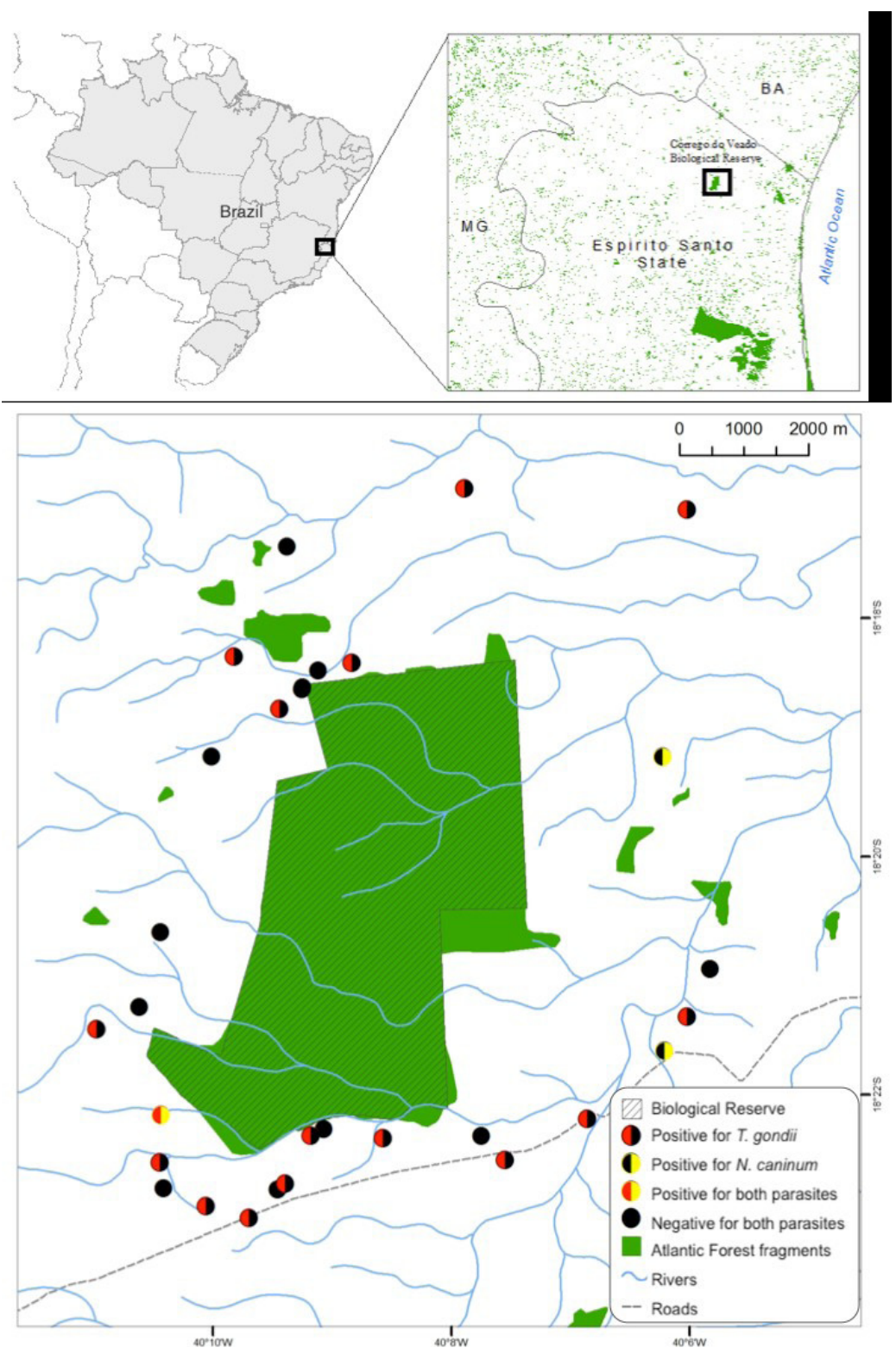

Figure 1. Geographical localization of Córrego do Veado Biological Reserve, municipality of Pinheiros, State of Espírito Santo, Brazil. Circles indicate rural properties with dogs tested for antibodies against Toxoplasma gondii and Neospora caninum, with: (red semicircle) positive for T. gondii; (yellow semicircle) positive for N. caninum; and (black semicircle) negative for both. 
Serum samples were collected from all 187 dogs (70 females and 117 males) that were present in the farms on the day of the visit from January 2011 to November 2012. The blood was collected from a jugular or cephalic vein and serum were kept at $-20{ }^{\circ} \mathrm{C}$ until analyses. The presence of $\operatorname{IgG}$ antibodies against T. gondii and $N$. caninum was determined by means of an Indirect Fluorescent Antibody Test (IFAT) with a cut-off of 1:16 for $T$. gondii (CAÑÓN-FRANCO et al., 2004) and 1:50 for $N$. caninum (SOUZA et al., 2002). All positive samples were diluted serially 2 -fold until the last positive dilution. Positives and negatives samples were added in each slide.

The Pearson's chi-square test $\left(\chi^{2}\right)$ was applied to evaluate whether the presence of antibodies against both parasites is associated with gender of dogs.

The handling of the dogs was previously authorized by the owners and the study was approved by the Ethics Committee for Animal Use of the Faculty of Veterinary Medicine, University of São Paulo, Brazil.

Antibodies to T. gondii were found in 77 (47.05\%) of $187 \mathrm{dogs}$ from 16 of 30 farms with titers of 32 in six dogs, 64 in 13 dogs, 128 in 18 dogs, 256 in 14 dogs, 512 in 22 dogs and 1.024 in four dogs. Also, 22 dogs (11.76\%) from three of the 30 farms tested positive for $N$. caninum antibodies, with titers of 100 in two dogs, 200 in five dogs, 800 in seven dogs, 12,800 in six dogs and 25,600 in two dogs. Sampling sites are shown in Figure 1.

Infection rates were not statistically different among female and male dogs: $32.86 \%$ (23/70) female dogs and 46.15\% (54/117) male dogs were positive for $T$. gondii $\left(\mathrm{X}^{2}=0.47 ; \mathrm{df}=1 ; \mathrm{p}>0.05\right)$; and $11.4 \%(8 / 70)$ of female and $11.9 \%(14 / 117)$ of male tested positive for $N$. caninum $\left(\mathrm{X}^{2}=0.52 ; \mathrm{df}=1 ; \mathrm{p}>0.05\right)$. One $\operatorname{dog}$ presented antibodies for both coccidian.

The results demonstrate that $T$. gondii and $N$. caninum are distributed along the farms surrounding the Córrego do Veado Reserve, in Espírito Santo State, Brazil. The farms from where the dog's samples were collected, originally, were all Atlantic Rainforest territory, that is the biome with the highest degree of degradation and is currently restricted to remnants (ICMBio, 2000; ACOSTA et al., 2014). In the Reserve natural fauna and flora are preserved, and dozens of species of animals and plants that are under threat of extinguishment are present (ICMBio, 2000; CHIARELLO, 2000).

As show in Figure 1, around $50 \%$ of the farms surrounding the Reserve presented positive dogs to one or two studied coccidian. The farm dogs and cats, definitive hosts for $N$. caninum and $T$. gondii, respectively, easily can go to the Reserve territory and leave fecal oocysts in the area. Studies showed that both avian and mammals' species can clinically react diversely to $T$. gondii infection and for some species the parasite could be fatal (DUBEY, 2010). With $N$. caninum much less information is available in wild animals in the world and in Brazil (revised by ALMERIA, 2013).

In relation to $T$. gondii, an important zoonotic agent, the dogs are only intermediate hosts and, in this study, they represent sentinels of the environmental contamination. Due the proximity of the farms with the protected areas, special care should be introduced to reduce the wildlife infection possibilities. The occurrence of $47.05 \%$, found in the rural dogs from Espírito Santo, is in agreement with results found in other parts of Brazil (revised by DUBEY et al., 2012; LOPES et al., 2011).

$N$. caninum infections are higher in rural dogs, probably related to availability of dead cattle carcasses and abortion products (DUBEY, 2013) in those areas. In the present study the occurrence of $11.76 \%$ is in the range of the results found in Brazilian dogs from rural areas (reviewed by DUBEY, 2013).

This is the first survey of frequency of occurrence of antibodies to $T$. gondii and $N$. caninum in dogs in the State of Espírito Santo, Brazil.

\section{References}

Acosta ICL, Costa AP, Gennari SM, Marcili A. Survey of Trypanosoma and Leishmania in wild and domestic animals in an Atlantic Rainforest fragment and surroundings in the State of Espírito Santo, Brazil. J Med Entomol 2014; 51(3): 686-693. PMid:24897863. http://dx.doi. org/10.1603/ME13177.

Almeria S. Neospora caninum and wildlife. Int Sch Res Notice Parasitol 2013 2013; 2013: 947347. PMid:27335866.

Anderson ML, Palmer CW, Thurmond MC, Picanso PC, Blanchard RE, Breitmeyer RE, et al. Evaluation of abortions in cattle attributable to neosporosis in selected dairy herds in California. J Am Vet Med Assoc 1995; 207(9): 1206-1210. PMid:7559072.

Cañón-Franco WA, Bergamaschi DP, Labruna MB, Camargo LMA, Silva JCR, Pinter A, et al. Occurrence of anti-Toxoplasma gondii antibodies in dogs in the urban area of Monte Negro, Rondônia, Brazil. Vet Res Commun 2004; 28(2): 113-118. PMid:14992241. http://dx.doi. org/10.1023/B:VERC.0000012114.71235.73.

Chiarello AG. Density and population size of mammals in remnants of Brazilian Atlantic Forest. Conserv Biol 2000; 14(6): 1649-1657. http:// dx.doi.org/10.1046/j.1523-1739.2000.99071.x.

Corbellini LG, Driemeier D, Cruz CFE, Gondim LFP, Wald V. Neosporosis as a cause of abortion in dairy cattle in Rio Grande do Sul, southern Brazil. Vet Parasitol 2002; 103(3): 195-202. PMid:11750112. http:// dx.doi.org/10.1016/S0304-4017(01)00600-8.

Dubey JP, Jenkins MC, Rajendran C, Miska K, Ferreira LR, Martins J, et al. Gray wolf (Canis lupus) is a natural definitive host for Neospora caninum. Vet Parasitol 2011; 181(2-4): 382-387. PMid:21640485. http:// dx.doi.org/10.1016/j.vetpar.2011.05.018.

Dubey JP, Lago EG, Gennari SM, Su C, Jones JL. Toxoplasmosis in humans and animals in Brazil: high prevalence, high burden of disease, and epidemiology. Parasitology 2012; 139(11): 1375-1424. PMid:22776427. http://dx.doi.org/10.1017/S0031182012000765.

Dubey JP, Lindsay DS. A review of Neospora caninum and neosporosis. Vet Parasitol 1996; 67(1-2): 1-59. http://dx.doi.org/10.1016/S03044017(96)01035-7.

Dubey JP. Neosporosis in dogs. Commonwealth Agricultural Bureau Reviews 2013; 8(55): 1-26. http://dx.doi.org/10.1079/PAVSNNR20138055.

Dubey JP. Toxoplasmosis of animals and humans. 2nd ed. Boca Raton: CRC Press; 2010. 313 p.

Fournier GFSR, Lopes MG, Marcili A, Ramirez DG, Acosta ICL, Ferreira JIGS, et al. Toxoplasma gondii in domestic and wild animals from forest fragments of the municipality of Natal, northeastern Brazil. Rev Bras 
Parasitol Vet 2014; 23(4): 501-508. PMid:25517529. http://dx.doi. org/10.1590/S1984-29612014092.

Gondim LFP, McAllister MM, Pitt WC, Zemlicka DE. Coyotes (Canis latrans) are definitive hosts of Neospora caninum. Int J Parasitol 2004; 34(2): 159-161. PMid:15037103. http://dx.doi.org/10.1016/j. ijpara.2004.01.001.

Instituto Chico Mendes de Conservação da Biodiversidade - ICMBio. Plano de manejo da reserva biológica do córrego do veado: reserva biológica do Córrego do Veado. Brasília: ICMBio; 2000 [cited 2016 Mar 10]. Available from: http://www.icmbio.gov.br/portal/images/stories/docs-planos-de manejo/corrego_do_veado_pm.pdf

King JS, Šlapeta J, Jenkins DJ, Al-Qassab SE, Ellis JT, Windsor PA. Australian dingoes are definitive hosts of Neospora caninum. Int J Parasitol 2010; 40(8): 945-950. PMid:20149793. http://dx.doi.org/10.1016/j. ijpara.2010.01.008.

Lopes MG, Hernandez M, Lima JTR, Grisi Filho JHH, Gennari SM. Occurrence of antibodies anti-Toxoplasma gondii and anti-Neospora caninum in dogs from Natal, RN, Brazil. Braz J Vet Res Anim Sci 2015; 52(2): 120-124. http://dx.doi.org/10.11606/issn.1678-4456.v52i2p120-124.
Lopes MG, Mendonça IL, Fortes KP, Amaku M, Pena HFJ, Gennari SM. Presence of antibodies against Toxoplasma gondii, Neospora caninum and Leishmania infantum in dogs from Piauí. Rev Bras Parasitol Vet 2011; 20(2): 111-114. PMid:21722484. http://dx.doi.org/10.1590/S198429612011000200004

McAllister MM, Dubey JP, Lindsay DS, Jolley WR, Wills RA, McGuire AM. Dogs are definitive hosts of Neospora caninum. Int J Parasitol 1998; 28(9): 1473-1479. PMid:9770635. http://dx.doi.org/10.1016/S00207519(98)00138-6.

Raimundo JM, Guimarães A, Moraes LMB, Santos LA, Nepomuceno LL, Barbosa SM, et al. Toxoplasma gondii and Neospora caninum in dogs from the state of Tocantins: serology and associated factors. Rev Bras Parasitol Vet 2015; 24(4): 475-481. PMid:26689184. http://dx.doi. org/10.1590/S1984-29612015068.

Souza SLP, Guimarães JS Jr, Ferreira F, Dubey JP, Gennari SM. Prevalence of Neospora caninum antibodies in dogs from dairy cattle farms in Paraná, Brazil. J Parasitol 2002; 88(2): 408-409. PMid:12054023. http://dx.doi. org/10.1645/0022-3395(2002)088[0408:PONCAI]2.0.CO;2. 